\title{
Study on feeding effect of dietary protein sources of on blood or milk urea nitrogen in native cows
}

\author{
N. R. Sarker*, K.S. Huque and M. Asaduzzaman \\ Bangladesh Livestock Research Institute \\ Savar, Dhaka-1341 \\ *Corresponding author: sarkernr62@yahoo.com
}

\begin{abstract}
A feeding trial with 30 Pabna milking cows of 2 to 4 parities dividing equally into 5 groups was conducted to determine the effect of feeding protein from different sources on blood or milk urea nitrogen, and milk yield or protein content in native cows. Considering a group of cows fed a diet of rice straw and concentrate as the control $\left(\mathrm{T}_{0}\right)$, two out of the rests were fed either with urea-molasses straw (UMS) $\left(T_{1}\right)$ or Matikalai (Vigna mungo) hay $\left(\mathrm{T}_{2}\right)$ as sources of basal roughage. The rest two groups of cows were fed the control diet replacing percent $(\%)$ of feed protein by the amount of urea and molasses fed to UMS group. The amount of urea and molasses was fed daily either in two meals $\left(\mathrm{T}_{3}\right)$ or fed to cows mixing with other concentrate feed $\left(\mathrm{T}_{4}\right)$. Feeding a basal diet of UMS, DS or leguminous hay did not affect milk protein (\%) and daily milk production Feeding urea and molasses in meals or mix $\left(\mathrm{T}_{3}\right.$ and $\left.\mathrm{T}_{4}\right)$ did not affect significantly (p>0.05) BSU and MUN contents. It indicates that feeding urea and molasses in two meals in a day either as a single mix of the two or as a mix of the two with concentrates significantly ( $>0.05)$ reduced the concentration of BSU or MUN without having any change in milk protein (\%) of the cows. Dry matter (DM) intake was significantly $(\mathrm{p}<0.05)$ higher in $\mathrm{T}_{1}$ treatment group followed by $\mathrm{T}_{4}, \mathrm{~T}_{0}, \mathrm{~T}_{3}$ and $\mathrm{T}_{2}$, respectively. Similarly, CP intake was significantly $(\mathrm{p}<0.05)$ higher in $\mathrm{T}_{1}$ and $\mathrm{T}_{2}$ treatment groups followed by $T_{3}$ and $T_{4}$ treatment groups. The values of CP intake were 490, 770, 760, 630 and $580 \mathrm{~g} /$ day for treatment groups $\mathrm{T}_{0}, \mathrm{~T}_{1}, \mathrm{~T}_{2}, \mathrm{~T}_{3}$, and $\mathrm{T}_{4}$, respectively. Feedings urea and molasses as meals $\left(\mathrm{T}_{3}\right)$ significantly $(\mathrm{p}<0.05)$ reduced the fat content in milk compared with other treatment groups. Similar to $\mathrm{T}_{3}$, UMS feeding also significantly $(\mathrm{p}<0.05)$ reduced fat content in milk compared to Matikalai hay and $\mathrm{T}_{4}$ treatment groups. Milk urea nitrogen (MUN) content in morning milk was lower compared to evening milk. These data showed that feeding urea or protein of organic sources had effect on BSU and MUN contents in the morning milk but had no significant effect on evening milk. The lower BSU or MUN content in milk of the cows fed urea and molasses either in daily meals or as mix with concentrates may be due mainly to a lower CP intake compared to UMS and Matikalai. Therefore, it may be concluded that feeding urea or organic protein had no significant effect on milk protein percent.
\end{abstract}

(Keywords: Blood urea nitrogen, milk urea nitrogen, urea molasses straw, meals \& mix)

\section{Introduction}

Urea, an end- product of protein metabolism, turns into ammonia primarily in the liver. Animals convert excess ammonia to urea because it is toxic while urea is not. The 
concentration of urea in milk is referred to as milk urea nitrogen (MUN), while the concentration of urea in blood is referred to as blood urea nitrogen (BUN). Urea concentration is typically analyzed on-farm as MUN because it is easier, less invasive and less expensive to sample. In addition, because urea passively diffuse from the blood in the mammary gland into milk, changes in BUN will be reflected in MUN (Jim and Mary, 2007). The MUN values on-farms can vary significantly due to a variety of nondietary and dietary factors. Non-dietary factors such as breed, parity, days in milk, milk production and feeding to milking interval can all affect MUN values. Diet or ration has the greatest effect on MUN values, however, with high MUN values indicating excess protein in the diet or a deficiency in energy.

Urea concentration in milk and plasma are closely related (Gustafssaon and Plamquist, 1993). Several investigators have suggested the possibility of using either of them as an indicator of dietary protein status and feeding adequacy in dairy cows (Roseler et al., 1993; Baker et al., 1995; Jonker et al., 2002). The main factor influencing these concentrations is not the amount of protein ingested as per requirement, but the relationship between protein and fermentable carbohydrate in ration (Olter and Wiktorsson, 1983). The amount of nitrogen $(\mathrm{N})$ required by the microbes is determined by the amount of available carbohydrate. If dietary protein is fed above the level needed by the microbes, the ammonia will be converted to urea in the liver and excreted in the urine. Feeding more energy will increase the nitrogen requirement by the microbes and promote the use of excess ammonia (Van Soest, 1994). A proper balance of protein and energy or more specifically degradable protein and rapidly fermentable carbohydrate allows the dairy cows to make the best possible use of protein in the diet. This could mean higher production, lower feed costs and less environmental impact from $\mathrm{N}$ in manure. As a guideline $30-40 \%$ of the diet should be represented by non-structural carbohydrate to maintain optimum rumen health and function (Nocek, 1997). It is difficult however to make recommendations for crude protein $(\mathrm{CP})$. The amount of $\mathrm{CP}$ to include in the diet will depend on milk yield, milk protein percentage, growth rate, body size, energy content and type, as well as amino acid composition and degradability of dietary protein. Generally, the amount of $\mathrm{CP}$ in the diet will need to be increased if the requirement for rumen degradable protein (RDP) is not meet (NRC, 2001). 
The type of dietary protein will determine how much ammonia is produced and consequently, the concentration of MUN. Feedstuffs such as alfalfa hay, canola and oats, which are rapidly degradable in the rumen, results in higher ammonia production. Milk urea nitrogen concentration tends to increase when this type protein is fed. Feedstuffs that are more slowly degraded in the rumen, such as brewers and distiller's grain and corn gluten meal, produce less ammonia, which results in a lower urea nitrogen concentration. Besides the effect of protein and energy, MUN concentration may also vary by season, month, parity, breed, stage of lactation and time of sampling. Researchers (Godden et al., 2001) found that concentrations were highest from July to September and in cows between 60-150 days in milk. Milk urea concentration was lowest in first lactation cows as well as cows in their first 60 days in milk or after 150 days in milk. The rate of decline between mid and late lactation was larger in animals in their second lactation or greater (Godden et al., 2001). It is also reported that a negative relationship exists between high urea concentration and reproductive performances in dairy cows (Carroll et al., 1994; Butler, 1998). Hence, implementing routine use of milk urea level as an indicator in dairy herd could improve feeding efficiency.

When feed protein metabolism in ruminants produces urea in the liver and recycles or blood urea filters into milk urea nitrogen (MUN), an indicator of protein status in diets or feeding urea as one of the non-protein nitrogen sources for ruminants is scientifically acceptable throughout the world; a section of environmentalists, policy makers or even professionals often raise question of residual effects in milk and/or meat of fattening and/or dairy cattle fed with diets containing urea. In Bangladesh, due to fodder scarcity, dairy and fattening farmers often use for urea supplemented diet or urea molasses straw based diet for high yielding dairy cows and fattening animals. However, the effect of these feeding systems on milk or plasma urea concentration, in relation to different sources of protein needs to be investigated. Therefore, the current study was undertaken to investigate of different sources of protein on milk urea nitrogen and serum urea nitrogen in native dairy cows.

\section{Materials and Methods}

To determine the effect of feeding different sources of protein on plasma or milk urea nitrogen in milk, a feeding trial on 30 Pabna milking cows of 2 to 4 parities dividing 
equally into 5 groups was conducted to determine the effect of feeding of different sources of protein (organic or in-organic) on blood or milk urea nitrogen, and milk yield or protein content.

Considering a group of cows fed a diet of rice straw and concentrate as the control $\left(\mathrm{T}_{0}\right)$, two out of the rests was fed either with urea-molasses straw (UMS) (T 1 ) or Matikalai (Vigna mungo) hay $\left(\mathrm{T}_{2}\right.$ ) as sources of basal roughage. The rest two groups of cows were fed the control diet replacing \% of feed protein by the amount of urea and molasses fed to UMS group. The amount of urea and molasses was fed daily either in two meals $\left(\mathrm{T}_{3}\right)$ or fed to cows mixing with other concentrate feed $\left(\mathrm{T}_{4}\right)$.

All the cows were kept in individual stalls, roughages were fed ad libitum and concentrate mixture containing $45 \%$ wheat bran, 24\% Khesari bran, 12\% Til oil cake, $12 \%$ soybean meal, $4 \%$ fishmeal, $2.0 \%$ oyster-shell, $0.5 \%$ DCP and $0.5 \%$ common salt, was supplied twice daily. Having adjusted the cows with the diets for 20 days, a 20 days feeding trial was conducted, when feed intake and samples of blood and milk were collected.

Milk samples were collected from individual cow after feeding the experimental diets in the morning and evening milking. Samples were collected from milk bucket after complete milking and mixing thoroughly.

\section{Urea molasses straw (UMS)}

In a container, $1500 \mathrm{~g}$ urea and $12 \mathrm{~kg}$ molasses were dissolved in 25 litre of water that made up urea molasses solution. This solution was then sprinkled into $50 \mathrm{~kg}$ rice straw and urea molasses rice straw (UMS) was packed in a heap and covered with polythene sheet. Urea molasses straw was fed to the experimental cows' ad libitum basis and supplied thrice in a day. Urea molasses straw was prepared everyday as per the requirements of cows.

\section{Determination of MUN}

Samples were analyzed for milk urea content (MUN) using a Colorimetric pdimethylaminobenzaldehyde (DMAB) method as described by Bector et al, (1998). Milk samples were warmed at room temperature $\left(30^{\circ} \mathrm{C}\right)$ and mixed well. Milk $(10 \mathrm{ml})$ was deproteinsed with $12 \%$ TCA solution $(10 \mathrm{ml})$, allowed to stand for one hour and filtered 
through a Whatman paper No. 1. Centrifuged the filtrate at $3000 \mathrm{x}$ g for 30 minutes. Clear supernatant $(2 \mathrm{ml})$ was mixed with $2 \mathrm{ml}$ of DMAB reagent $(1.6 \mathrm{~g} \mathrm{DMAB}+90 \mathrm{ml}$ ethanol $+10 \mathrm{ml}$ concentrate $\mathrm{HCl}$ ). Spectrophotometer absorbance was taken at $425 \mathrm{~nm}$. Concentration of MUN in milk was calculated from

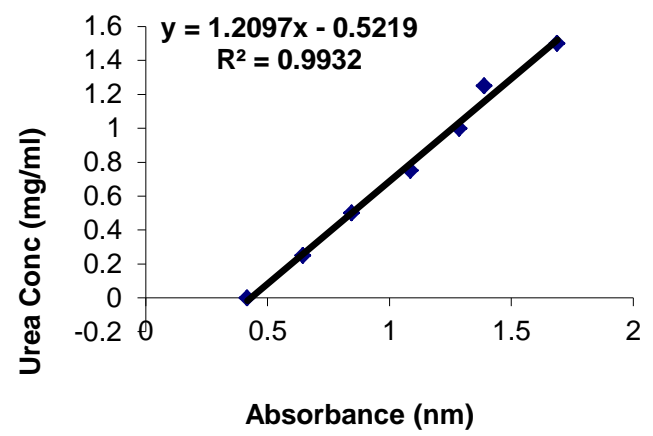

\section{Determination of BSU}

Fig. 1. Urea Standard Curve

Blood samples were collected from jugular vein of a cow after feeding the diets using heparinised tubes. Immediately after collection, samples were placed on ice and refrigerated for $1.0 \mathrm{~h}$. followed by centrifugation. Plasma was removed and serum samples were analyzed for urea content (BSU) using a colorimetric method described by Patton and Crouch (1977).

Daily feed intake was measured by deducting the amount of feed remained in the manger in each day from the total feed supplied. The feed samples were collected daily, composited and analyzed for nutrient composition using methods described by AOAC (2004).

\section{Feeding and management}

The animals were adjusted to their diets for 20 days before starting the actual feeding experiment. De-worming and spraying against mites and other external parasites were done before the trial. During the feeding trial, the animals were individually confined in their respective feeding stall. The experimental cows were watched everyday in the morning and stalls were cleaned two times in a day before milking. During the adjustment period, the amounts of feed given to the animals were increased gradually until they reached to a constant level of forage intake required for each treatment. Feed was offered to the animals thrice in a day, at 8:00 am , 12:00am and 4:00 pm. The concentrate was given in the morning and afternoon before feeding the roughages and milking. Fresh drinking water was made available to the animals at all times. 


\section{Digestibility trial}

A digestibility trial was conducted at the mid of the experimental period to determine the digestibility of nutrients. At the mid of the feeding trial, a digestion trial was conducted with 5 days collection period of fecal output on the same stall. During the digestibility trial, data were recorded on the daily amount of feed offered, residues left and faces voided. The total amount of feces voided for 24 hours by the individual animal was collected quantitatively at 8:00 a.m. daily. It was weighed and representative samples of each animal were put in polythene bags and $1 / 20^{\text {th }}$ the fresh daily sample was taken for dry matter and crude protein analysis. The fecal samples were collected daily and stored in refrigerator $\left(-20^{0} \mathrm{C}\right)$ for their further chemical analysis. Feces samples of 5 days collection were mixed and $10 \%$ sample was used for chemical analysis.

\section{Statistical analysis of data:}

Data were analyzed by using General Linear Model Procedures of SPSS computerized software to determine treatment effects. When treatment effect was significant, Duncan Multiple Range Test (DMRT) was used to test significant differences among the treatment means.

\section{Results and discussion}

The effect of feeding dietary sources of protein on MUN and BSU are presented in Table 1. Feeding a basal diet of UMS, DS or leguminous hay did not affect milk protein (\%) and daily milk production (Table 1). Feeding urea and molasses in meals or mix $\left(\mathrm{T}_{3}\right.$ and $\left.\mathrm{T}_{4}\right)$ did not affect significantly $(\mathrm{p}>0.05) \quad \mathrm{BSU}$ and MUN contents. It indicates that feeding urea and molasses in two meals a day either as a single mix of the two or as a mix of the two with concentrates significantly $(\mathrm{p}>0.05)$ reduced the concentration of BSU or MUN without having any change in milk protein (\%) of the cows. Graphical presentation of BSU and MUN under different dietary treatment is also shown in Fig. 2. 
Fig. 2. BSU and MUN concentration of different

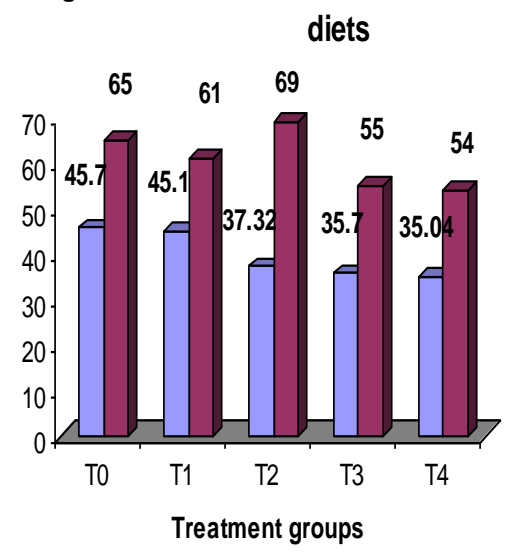

MUN contents in morning and evening milk under different dietary groups

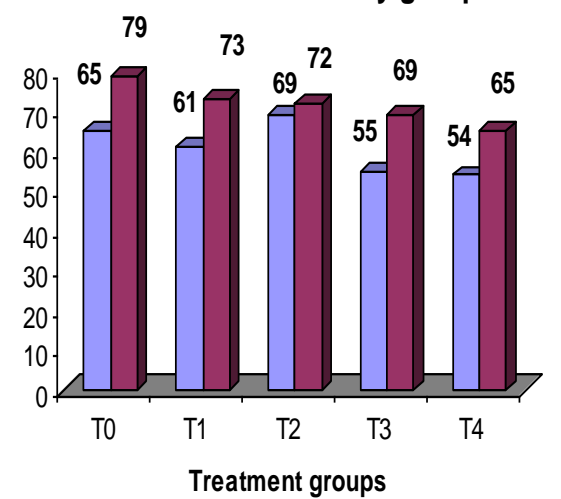

$\square$ Morning

Evening

Table 1. Milk urea nitrogen (MUN), blood serum urea (BSU) and nutrient intake by cows under different treatment groups

\begin{tabular}{|c|c|c|c|c|c|c|}
\hline Parameters & $\begin{array}{l}\mathrm{T}_{0} \\
\text { (Control) }\end{array}$ & $\begin{array}{l}\mathrm{T}_{1} \\
\text { (UMS) }\end{array}$ & $\begin{array}{l}\mathrm{T}_{2} \\
\text { (Matikalai hay) }\end{array}$ & $\begin{array}{l}T_{3} \\
\text { (Meal ) }\end{array}$ & $\begin{array}{l}T_{4} \\
\text { (Mix.) }\end{array}$ & Sig. \\
\hline $\begin{array}{l}\text { BSU (Blood serum } \\
\text { urea) (mg/dl) }\end{array}$ & $45.70^{\mathrm{c}}$ & $45.10^{c}$ & $37.32^{\mathrm{ab}}$ & $35.70^{\mathrm{a}}$ & $35.04^{\mathrm{a}}$ & $*$ \\
\hline $\begin{array}{l}\text { MUN in Morning } \\
(\mathrm{mg} / \mathrm{dl})\end{array}$ & $65.00^{\mathrm{d}}$ & $61.00^{\mathrm{c}}$ & $69.00^{\mathrm{b}}$ & $55.00^{\mathrm{a}}$ & $54.00^{\mathrm{a}}$ & $*$ \\
\hline $\begin{array}{l}\text { MUN in evening } \\
(\mathrm{mg} / \mathrm{dl})\end{array}$ & $79.00^{\mathrm{d}}$ & $73.00^{\mathrm{a}}$ & $72.00^{\mathrm{a}}$ & $69.00^{\mathrm{b}}$ & $65.00^{c}$ & $*$ \\
\hline Milk fat (\%) & $4.23^{\mathrm{d}}$ & $4.01^{\mathrm{c}}$ & $4.72^{\mathrm{a}}$ & $3.78^{\mathrm{b}}$ & $4.67^{\mathrm{a}}$ & $*$ \\
\hline Milk protein $(\%)$ & 3.65 & 3.62 & 3.65 & 3.64 & 3.69 & NS \\
\hline $\begin{array}{l}\text { Milk production } \\
(\mathrm{kg} / \text { day })\end{array}$ & 3.5 & 3.6 & 3.6 & 3.1 & 3.2 & NS \\
\hline $\begin{array}{l}\text { DM intake } \\
\text { (kg/day/Cow) }\end{array}$ & $7.24^{\mathrm{a}}$ & $7.76^{\mathrm{b}}$ & $7.06^{\mathrm{c}}$ & $7.12^{\mathrm{c}}$ & $7.45^{\mathrm{a}}$ & * \\
\hline $\begin{array}{l}\text { OM intake } \\
\text { (kg /day/Cow) }\end{array}$ & $6.33^{\mathrm{a}}$ & $6.87^{\mathrm{b}}$ & $6.20^{\mathrm{c}}$ & $6.22^{\mathrm{c}}$ & $6.53^{\mathrm{a}}$ & $*$ \\
\hline $\begin{array}{l}\text { CP intake } \\
\text { (g/day/Cow) }\end{array}$ & $490^{\mathrm{d}}$ & $770^{\mathrm{a}}$ & $760^{a}$ & $630^{\mathrm{b}}$ & $580^{\mathrm{c}}$ & $*$ \\
\hline $\begin{array}{l}\text { ME intake (MJ/day) } \\
\text { (Calculated) }\end{array}$ & $62.00^{\mathrm{a}}$ & $65.31^{\mathrm{b}}$ & $60.74^{\mathrm{a}}$ & $61.20^{\mathrm{a}}$ & $63.47^{\mathrm{ab}}$ & * \\
\hline
\end{tabular}

$\mathrm{Dl}=$ Deci litre; NS $=$ Non-significant $*=$ Significant $(\mathrm{p}<0.05) ;$ Means with different subscripts in the same row differ significantly $(\mathrm{p}<0.05)$ 
The MUN values in this experiment is a bit higher compared with the findings of Hwang, et al., 2000; Baker et al., 1995 and Rosler et al., 1993. They reported that the optimum concentration of MUN for a herd ranges from 12 to $17 \mathrm{mg} / \mathrm{dL}$ in European cattle but the literatures in relationship to MUN for native cattle of Bangladesh are scanty. So, this findings was an attempt to determine the MUN and BUN in relation to feeding of different sources of protein.

Dry matter $(D M)$ intake was significantly $(\mathrm{p}<0.05)$ higher in $\mathrm{T}_{1}$ treatment group followed by $T_{4}, T_{0}, T_{3}$ and $T_{2}$, respectively. Similarly, $C P$ intake was significantly $(\mathrm{p}<0.05)$ higher in $T_{1}$ and $T_{2}$ treatment groups followed by $T_{3}$ and $T_{4}$ treatment groups. The values of $C P$ intake were 490, 770, 760, 630 and $580 \mathrm{~g} /$ day for treatment groups $\mathrm{T} 0, \mathrm{~T}_{1}, \mathrm{~T}_{2}, \mathrm{~T}_{3}$, and T4, respectively. Feedings urea and molasses as meals $\left(\mathrm{T}_{3}\right)$ significantly $(\mathrm{p}<0.05)$ reduced the fat content in milk compared to other treatment groups. Similar to $\mathrm{T}_{3}$, UMS feeding also significantly $(\mathrm{p}<0.05)$ reduced fat content in milk compared to Matikalai hay and $\mathrm{T}_{4}$ treatment groups. Milk urea nitrogen (MUN) content in morning milk was lower compared to evening milk. This similar findings also reported by Broderick and Clayton, (1997), they reported that MUN concentrations was generally lower for samples collected at morning milking. Others explained that the differences in MUN in morning or evening milk, may be influenced by the differences in feeding to milking intervals (Godden, 1998). Fig. 3. shows the graphical presentation of morning and evening MUN status in milk under different dietary groups. These data showed that feeding urea or protein of organic sources had effect on BSU and MUN contents in the morning milk but had no significant effect on evening milk. The lower BSU or MUN content in milk of the cows fed urea and molasses either in daily meals or as mix with concentrates may be due mainly to a lower CP intake compared to UMS and Matikalai. Dhali et al., (2005) studied the effect of urea supplemented and urea treated straw based diet on milk urea concentration in crossbred Kiran-Fries and reported that MUN is a dietary monitor for dairy cows. Other researchers (Garcia, et al., 1997; Hof et al., 1997) also observed the similar results. Further, it is noted that the main factor influencing these concentrations is not the amount of protein ingested as per requirement, but the relationship between protein and fermentable carbohydrate in ration (Older and Wiktorsson, 1983; Roseler et al., 1993 and Lykos et al., 1997). 


\section{Digestibility of nutrients:}

The digestibility of nutrient of different test diets is presented in Table 2. It reveals that the significantly $(\mathrm{p}<0.05)$ higher $\mathrm{DM}$ digestibility was observed in $\mathrm{T}_{3}$ and $\mathrm{T}_{4}$ treatment groups followed by $T_{1}, T_{0}$ and $T_{2}$, respectively. But the values were not significant ( $p>0.05$ ) between $\mathrm{T} 3$ and $\mathrm{T}_{4}$ treatment groups. Similarly, dry matter digestibility was not significant $(\mathrm{p}>0.05)$ between $\mathrm{T}_{0}$ and $\mathrm{T}_{2}$. The results indicated that the feeding of urea and molasses in the form of meals and mix did not affect the DM digestibility between $\mathrm{T}_{3}$ and $\mathrm{T}_{4}$ treatments. The percent digestibility of $\mathrm{CP}$ was significantly $(\mathrm{p}<0.05)$ higher in $\mathrm{T}_{4}$ treatment group followed by $\mathrm{T}_{3}, \mathrm{~T}_{1}, \mathrm{~T}_{2}$ and $\mathrm{T}_{0}$, respectively. Similar to DM digestibility, the values were not significant $(\mathrm{p}>0.05)$ between $\mathrm{T}_{3}$ and $\mathrm{T}_{4} ; \mathrm{T}_{0}$ and $\mathrm{T}_{2}$ treatment groups. It is noted that $\mathrm{CP}$ digestibility was significantly higher in $\mathrm{T}_{2}$ treatment group which may due to the difference in basal diet. This finding was inconsistent with the results of Afzalzadeh et al., (2010) and Hristov et al., (2004) they reported that the digestibility of DM and CP didn't changes when CP and RDP levels were changes from 158 to $183 \mathrm{~g} / \mathrm{kg}$ and 94 to $116 \mathrm{~g} / \mathrm{kg}$, respectively.

Table 2. Digestibility Coefficient of different nutrients under different treatment groups

\begin{tabular}{|c|c|c|c|c|c|c|}
\hline Parameters & $\begin{array}{l}\mathbf{T}_{\mathbf{0}} \\
(\text { mean } \pm \\
\mathrm{SE})\end{array}$ & $\begin{array}{l}\mathbf{T}_{1} \\
(\text { mean } \pm \\
\mathrm{SE})\end{array}$ & $\begin{array}{l}\mathbf{T}_{2} \\
(\text { mean } \pm \\
\mathrm{SE})\end{array}$ & $\begin{array}{l}\mathbf{T}_{\mathbf{3}} \\
(\text { mean } \pm \\
\mathrm{SE})\end{array}$ & $\begin{array}{l}\mathbf{T}_{4} \\
(\text { mean } \pm \\
\text { SE) }\end{array}$ & $\begin{array}{l}\text { Level } \\
\text { of sig. }\end{array}$ \\
\hline Dry matter (\%) & $\begin{array}{l}53.33^{\mathrm{c}} \pm \\
1.29\end{array}$ & $\begin{array}{l}55.28^{\mathrm{b}} \pm \\
0.61\end{array}$ & $\begin{array}{l}53.14^{\mathrm{c}} \pm \\
1.30\end{array}$ & $\begin{array}{l}56.18^{\mathrm{a}} \pm \\
0.97\end{array}$ & $\begin{array}{l}56.44^{\mathrm{a}} \pm \\
1.25\end{array}$ & $*$ \\
\hline Organic matter $(\%)$ & $\begin{array}{l}57.17^{\mathrm{c}} \pm \\
1.15\end{array}$ & $\begin{array}{l}58.14^{\mathrm{b}} \pm \\
0.56\end{array}$ & $\begin{array}{l}57.22^{c} \pm \\
1.19\end{array}$ & $\begin{array}{l}59.65^{\mathrm{a}} \pm \\
0.90\end{array}$ & $\begin{array}{l}60.60^{\mathrm{a}} \pm \\
1.09\end{array}$ & $*$ \\
\hline Crude protein $(\%)$ & $\begin{array}{l}50.70^{\mathrm{e}} \pm \\
1.36\end{array}$ & $\begin{array}{l}59.80^{\mathrm{b}} \pm \\
0.74\end{array}$ & $\begin{array}{l}65.04^{\mathrm{a}} \pm \\
1.15\end{array}$ & $\begin{array}{l}56.08^{\mathrm{d}} \pm \\
1.44\end{array}$ & $\begin{array}{l}58.59^{c} \pm \\
1.15\end{array}$ & $*$ \\
\hline $\operatorname{Ash}(\%)$ & $\begin{array}{l}30.49^{c} \pm \\
2.32\end{array}$ & $\begin{array}{l}39.86^{\mathrm{a}} \pm \\
1.08\end{array}$ & $\begin{array}{l}27.62^{\mathrm{d}} \pm \\
2.10\end{array}$ & $\begin{array}{l}35.60^{\mathrm{b}} \pm \\
1.64\end{array}$ & $\begin{array}{l}26.98^{\mathrm{e}} \pm \\
2.30\end{array}$ & $*$ \\
\hline
\end{tabular}

Means with different subscripts in the same row differ significantly $(\mathrm{p}<0.05)$

\section{Conclusion}

The results showed that feeding urea or protein of organic sources had effect on BSU and MUN contents in morning milk and had no significant effect on evening milk. The lower BSU or MUN content in milk of cows fed urea and molasses either in daily meals or mix with concentrate may be due to lower CP intake compared to UMS and matikalai . 
Therefore, it may be concluded that feeding urea or organic protein had no significant effect on milk protein percent.

\section{References}

Afzalzadeh, A., Rafiee, H, Khadem, A.A., and Asadi, A. 2010. Effects of ratios of nonfibre carbohydrates to rumen degradable protein in diets of Holstein cows: 1. Feed intake, digestibility and milk production. South African J. Anim. Sci., 40(3):204-212.

AOAC. 2004. Officials Methods of Analysis $24^{\text {th }}$ ed. AOAC, Washington, DC, USA.

Bector, B.S. , Moti Ram, Singhal, O.P. 1998. Rapid platform test for the detection/ determination of added urea in milk. Ind. Dairyman. 50:59-62.

Butler, W. R. 1998. Review: Effect of protein nutrition on ovarian and uterine physiology in dairy cattle. J. Dairy Sci., 81: 2533-2539.

Broderick, G.A. and Clayton, M.K. 1997. A statistical evaluation of animal and nutritional factors influencing concentrations of milk urea nitrogen. J. Dairy Sci., 80: 2964-2971.

Baker, L. D. Ferguson, J. D. Chalupa, W., 1995. Responses in urea and true protein of milk to different protein feeding schemcs for dairy cows. J. Dairy Sci., 8:2964-2971.

Carrol, D.J., Hossian, F.R., Keller, M.R. 1994. Effect of supplementation fishmeal on the lactation and reproductive performance of dairy cows. J. Dairy Sci., 77: 3058-3072.

Dhali, A., Mehla, R.K., Sirohi, S.K., Mech, A. and Karunakaran, M. 2005. Monitoring feeding adequacy in dairy cows using milk urea and milk protein contents under farm condition. Asian-Aust. J. Anim. Sci., 12:1742-1748

Garcia , A.D., Linn, J.G., Stewart, S.C. Olson, J.D. and Olson, W.G. 1997. Evaluation of milk urea nitrogen (MUN) as a dietary monitor for dairy cows. J. Dairy Sci., 80(Suppl. 1):161 (Abstract)

Godden, S.H. 1998. Evaluation of a milk urea assay, and the relationship between milk urea concentrations and nutritional management and performance in Ontario dairy herds. D.V. Sc. Thesis, University of Guelph, Guelph, ON, Canada.

Godden, S.M., Kelton, D..F., Lissemore, K.D., alton, J.S., Leslie, K.E. and Lumsden, J.H. 2001. Milk urea testing as a tool to monitor reproductive performance in Ontario dairy herds. J. Dairy Sci., 84: 1397-1406

Gustafsson, A.H., Palmquist, D.L. 1993. Diurnal variation of rumen ammonia, serum and milk urea in dairy cows at high and low yields. J. Dairy Sci., 76:475-484. 
Hwang, S.Y., Mei-Ju, L. Peter, W.C. 2000. Monitoring nutritional status of dairy cows in Taiwan using milk protein and milk urea nitrogen. Asian-Aust. J. of Anim. Sci., 13:16671673.

Hof, G., Versson, M.D. Lenaers, P.J. and Tamminga, S. 1997. Milk urea nitrogen as a tool to monitor the protein nutrition of dairy cows. J. Dairy Sci., 80:3333-3340.

Hristov, A.N. Price, W.J. and Shafi, B. 2004. A meta-analysis examining the relationship among dietary factors, dry matter intake, and milk yield and milk protein yield in dairy cows. J. dairy Sci., 87:2184-2196.

Jim, L. and Mary, R.K. 2007. Milk urea nitrogen. University of Minnesota Dairy Extension. En.engormix.com/MA-dairy-cattle/news/milk urea nitrogen-t11726/p0.htm.

Jonker, J.S. , Khon, R.A. and Hight, J. 2002. Use of milk urea nitrogen to improve dairy cow diets. J. Dairy Sci., 86:939-946.

Lykos, T., Varga, G.A., and Casper, D. 1997. Varying degradation rate rates of total nonstructural carbohydrates: Effects on ruminal fermentation, blood metabolites and milk production and composition in high producing dairy cows. J. Dairy Sci., 80:3341-3355.

National Research Council. 2001. Nutrient requirements of dairy cattle. $7^{\text {th }}$ revised edition. National Academy Press, Washington, DC. USA.

Nocek, J.E. 1997. Bovine acidocis; Implications on laminitis. J. dairy Sci., 80:10051028.

Oltner, R. and Wiktorsson, H. 1983. Urea concentration in milk and blood as influenced by feeding varying amounts of protein and energy to dairy cows. Livestock Prod. Sci., 10: 457-467.

Patton, C.J. and Crouch, S. R. 1977. Anal. Chem., 49:464-469.

Roseler, D.K., Ferguson, J. D., Sniffen, C.J., Herrema, J., 1993. Dietary protein degradability effects on plasma and milk urea nitrogen and milk nonprotein nitrogen in Holstein cows. J. Dairy Sci., 76:525-584.

Van Soest, P. J. 1994. Nutritional ecology of the ruminant. $2^{\text {nd }}$ edition. Cornell University Press. United States, 291-303. 
